\title{
Armas brasileiras na América Central um estudo sob a perspectiva da
Política Nacional de Exportação de Material
de Emprego Militar - PNEMEM (1974-1991)*
}

\section{Brazilian arms in Central America \\ a study in the perspective of the Brazilian's Arms Transfer Policy - PNEMEM (1974-1991)}

Carlos federico domínguez aViLa Professor do Centro Universitário UNIEURO Doutor em História das Relações Internacionais pela Universidade de Brasília Unidade Asa Sul- Avenida das Nações, trecho 0- conjunto 5 Brasília - DF cdominguez_unieuro@yahoo.com.br

RESUMO O artigo avalia a Política Nacional de Exportação de Material de Emprego Militar e seu impacto nas relações brasileiro-centro-americanas durante os anos 1970 e 1980. Parte-se do critério que o comércio internacional de armas implica relevantes consequências políticas, econômicas e estratégicas, especialmente quando se trata de transferências para países em conflito interno ou regional. O texto utiliza fontes primárias resgatadas no Arquivo Histórico do Ministério das Relações Exteriores do Brasil (AHMRE). 
Palavras-chave Brasil, América Central, material de emprego militar, História das relações internacionais da América Latina

ABSTRACT The paper explores the Brazilian's Arms Transfer Policy and its impact in the Brazilian-Central American relations between 1970 and 1990. The text suggests that arms transfer has relevant politics, economics and strategic consequences, particularly in countries with national or regional conflicts. The paper uses some information from the Brazil's Foreign Affairs Archives.

Keywords Brazil, Central America, weapons, International relations of Latin American countries

\section{Introdução}

Em meados de 1977, quando o Brasil estava em vias de consolidarse como um dos dez países provedores ou fornecedores de armamento convencional avançado mais importantes do mundo, o Chanceler Antônio Francisco Azeredo da Silveira alertou o general Hugo de Andrade Abreu, Secretário Geral do Conselho de Segurança Nacional, de que "as exportações de material de emprego militar destinado a países em atrito implicam responsabilidade política irrecusável do governo do país exportador, em virtude de suas consequências no relacionamento entre as nações adversárias (...)". ${ }^{1}$ Eis um dos princípios fundamentais que orientam e percorrem os estudos sobre a política do comércio internacional de armas e sobre a própria política externa brasileira durante os decênios de 1970 e 1980. Igualmente, essa breve e categórica afirmação é importante porque conduz a uma dimensão especial e pouco conhecida das relações brasileiro-centro-americanas.

Com efeito, a transferência de rrmas $^{2}$ - ou material de emprego militar ${ }^{3}$ - também é um assunto de política externa. Tal constatação decorre do fato dos governos dos países exportadores estarem investidos da autoridade e do direito para autorizar - ou não autorizar - tais transferências. Igualmente os mesmos governos normalmente estão envolvidos no esforço mais amplo e abrangente de garantir a viabilidade da própria indústria da defesa, em

1 Antônio F. Azeredo da Silveira a Hugo de Andrade Abreu, Memorando secreto (DPG/DCS/DSI), Brasília, s.f. [circa 12.5.1977], Arquivo Histórico do Ministério das Relações Exteriores - no sucessivo AHMRE -: Pasta Especial PNEMEM-El Salvador.

2 O termo transferência de armas é utilizado para descrever todas as formas de transação de armas entre países, seja com base em doações, compras parceladas ou compras a vista.

3 O termo material de emprego militar utilizado pelo governo brasileiro inclui armamento convencional avançado, armamento ligeiro, munição, material logístico e de apoio. Vale acrescentar que a lista de material de emprego militar era susceptível de experimentar modificações e incluir novos produtos conforme os avanços da indústria de armamentos brasileira. 
função de uma série de argumentos de natureza política, econômica, social, ideológica, tecnológica e estratégica.

Em consequência, as transferências de armas, sobretudo para regiões em conflito, não podem ser consideradas como transações comerciais comuns entre países, devido às restrições impostas por considerações da política exterior global dos países fornecedores ou provedores. Estas restrições políticas são fundamentadas principalmente em argumentos de interesse e segurança nacional e, em menor medida, em uma série de princípios éticos mais ou menos aceitos, acatados e respeitados pelos principais exportadores de armamento. Entre tais princípios éticos convém ressaltar os seguintes: (i) não-transferências para regiões em tensão ou em conflito aberto; (ii) não-transferências para governos com propósitos agressivos respeito de terceiros países ou generalizada repressão interna; e (iii) não-transferências de armas que possam romper equilíbrios estratégicos regionais mais ou menos satisfatórios.

\section{O Brasil e a Política Nacional de Exportação de Material de Em- prego Militar - PNEMEM}

Dentre os acontecimentos mais importantes do mercado mundial de armamento convencional avançado durante o boom armamentista do decênio de 1970 destacou-se o surgimento e consolidação de um crescente número de fornecedores ou provedores - eis o caso do Brasil. Efetivamente, em uma década (1975-1985) o Brasil tornou-se um dos dez mais importantes fornecedores ou provedores de armamento convencional avançado do mundo. O Brasil conseguiu consolidar-se nesse competitivo mercado internacional devido ao fortalecimento da indústria da defesa e a uma eficiente associação do estado com as empresas públicas - como a Empresa Brasileira de Aeronáutica (EMBRAER) -, privadas - como a Engenheiros Especializados (ENGESA) - e mistas.

A origem, as transformações e as perspectivas da moderna indústria de defesa - ou complexo industrial-militar - brasileiro têm sido abordadas por uma dezena de consagrados autores, tanto brasileiros como estrangeiros. Ainda que um comentário aprofundado daqueles autores e obras está alem das possibilidades deste artigo, vale deixar registrados os trabalhos de Clóvis Brigagão, Renato P. Dagnino, Ethan B. Kapstein, Reiner Pungs, e Patrice Franko-Jones.

Paralelamente, no início da década de 1980, o complexo industrial-militar brasileiro estava constituído por mais de 300 empresas vinculadas direta ou indiretamente à produção de material de emprego militar. A indústria de armamentos brasileira empregava por volta de 100 mil pessoas. Aglutinava uma economia calculada em quatro bilhões de dólares, incluindo valores expressivos por conceito de exportações anuais - estima-se que durante o 
decênio de 1980 tais exportações flutuaram anualmente entre os US $\$ 200$ miIhões e US\$ 1 bilhão. Aeronaves, veículos blindados e artilharia, sistemas de navegação e radar, mísseis, navios de guerra e armas ligeiras (espingardas, pistolas, granadas) formavam parte dos inventários disponíveis no país. Vale acrescentar, ainda, que mais de $70 \%$ da produção brasileira de armamento era destinada ao mercado internacional. Note-se, ademais, que os produtos brasileiros - desenhados com base em tecnologia de mediana sofisticação - foram bem recebidos no mercado internacional, devido ao seu alto desempenho em operações reais de combate, às facilidades financeiras para as aquisições, ao baixo custo de manutenção, e aos preços competitivos, entre outras ponderações. Em consequência, entre 1971 e 1991, o Brasil foi capaz de exportar material de emprego militar para mais de 25 países.

Existem poucos estudos fundamentados em documentação primária sobre o impacto da crescente exportação de armas na política externa global do Brasil durante as décadas de 1970 e 1980. Tal situação, que não é exclusiva do país, deve ser atribuída tanto ao notório sigilo que normalmente predomina no processo de tomada de decisões, bem como ao desejo de manter restritas ou mascaradas informações consideradas sensíveis à segurança estatal de fornecedores e clientes. Mesmo assim, desde que o Brasil se tornou um importante newcomer a sua política exterior encontrouse submetida ao paradoxo de, por um lado, promover soluções negociadas para os conflitos internacionais e aspirar à busca da paz mundial - isto é, uma política exterior essencialmente pacífica -, e, por outro lado, consolidar-se como um dos dez principais exportadores de material de emprego militar no mundo. Dito paradoxo foi aparentemente resolvido mediante uma complicada avaliação de potenciais vantagens e desvantagens de caráter político, econômico e estratégico em cada um dos casos que circunstancialmente se apresentaram a partir do momento que o país começou a exportar este tipo de produtos.

Possivelmente o que mais interessa neste momento seja constatar que as autoridades brasileiras tinham plena consciência do caráter político que envolve a transferência de armamento. Isso se pode comprovar, por exemplo, com um Memorando interno do Itamaraty, de janeiro de 1977, no qual um funcionário de alto escalão justificou o seu argumento em favor das exportações de armamentos citando um importante documento interministerial onde se informava que:

A exportação de material militar atende aos interesses da política externa e pode ser instrumento valioso de afirmação e defesa da soberania nacional. $O$ aproveitamento das oportunidades criadas no mercado exterior, ao possibilitar a ampliação quantitativa e qualitativa da escala da produção interna, é fator de aumento da autonomia de abastecimento das Forças Armadas brasileiras e, consequentemente, de maior independência do País com relação aos fornecedores habituais de equipamento militar. Por outro lado, haveria importantes 
vantagens, políticas e econômicas, na vinculação de países importadores a fabricantes brasileiros de material por natureza do mais alto valor estratégico. O incremento das exportações deverá fortalecer, por conseguinte, a posição internacional do Brasil. ${ }^{4}$

O texto anterior é sumamente importante porque nele se reconhece que a venda de material de emprego militar é uma opção política de caráter estratégico susceptível de tornar-se um importante meio diplomático do estado brasileiro. Ao mesmo tempo, uma análise mais detalhada sugere que a exportação de armamento provocaria um importante impacto na política exterior global do Brasil ao colocar-se que a própria soberania do país dependeria da capacidade autônoma de produzir o armamento necessário para que as suas forças armadas pudessem, com efetividade, defender o estado de eventuais agressões externas. Complementarmente, essa capacidade autônoma de defesa era considerada de crucial importância para implementar uma política externa independente e congruente com a visão de país que os governos militares da época aspiravam conseguir no cenário latino-americano e mundial.

A pesquisa básica no Arquivo Histórico do Ministério das Relações Exteriores (AHMRE) e a leitura de bibliografia especializada na matéria permitem constatar que, a partir de 1974, uma equipe de trabalho interministerial - integrada por representantes dos Ministérios das Relações Exteriores, Fazenda, Marinha, Exército, Aeronáutica, Indústria e Comércio, do Estado Maior das Forças Armadas e da Secretaria-Geral do Conselho de Segurança Nacional - teria assentado as bases do que derivou na chamada Política Nacional de Exportação de Material de Emprego Militar (PNEMEM).

Segundo a documentação do AHMRE, a PNEMEM vigente no início dos anos oitenta incluía: as diretrizes gerais que orientavam a exportação brasileira de material de emprego militar, a lista de produtos de exportação restrita - e, portanto, sujeita à dita política -, e os procedimentos que deveriam ser adotados e seguidos em cada processo de tomada de decisões sobre o tema.

Com relação às diretrizes gerais cumpre citar documento assinado pelo então Chanceler Azeredo da Silveira reconhecendo que a PNEMEM poderia provocar consequências na política externa global do Brasil. O documento em aprecio sugere as seguintes ponderações:

I. por sua própria natureza, as exportações de material de emprego militar destinado a países em atrito implicam responsabilidade política irrecusável do governo

4 Paulo Tarso Flecha de Lima ao Secretário Geral, Memorando secreto (DPR), Brasília, 31.1.1977, AHMRE: Pasta Especial PNEMEM-EI Salvador. Segundo Paulo Tarso Flecha de Lima, o trecho citado é parte do "Relatório Final do Grupo Interministerial Itamaraty/Fazenda/ Marinha/Exército/Aeronáutica/Indústria e Comércio/EMFA/Secretaria Geral do CSN encarregado de propor as bases da política nacional em matéria de exportação de armamentos e munições", emitido em 1974. 
do país exportador, em virtude de suas possíveis consequências no relacionamento entre as nações adversárias e potencial que encerram de agravamento e acirramento de posições, suporte de hostilidade armada e perturbação maior da ordem e da harmonia internacionais;

II. se podem apresentar inconvenientes políticos, aquelas exportações, como todas as da mesma natureza, também são suscetíveis de conter vantagens políticas diversas, além das imediatas de ordem econômico, industrial e propriamente comercial (...);

III. sempre em tese, tal como a decisão de fornecer, a decisão de não fornecer determinado equipamento tem implicações políticas. A negativa de fornecer pode apresentar desvantagens nas relações bilaterais com o país interessado e mesmo em termos de política externa global do País;

IV. em uma mesma operação podem conviver repercussões políticas negativas e oportunidades políticas positivas, as primeiras predominando mas não excluindo as segundas. Eventualmente, as vantagens políticas inferiores, acrescentadas às vantagens econômicas imediatas, podem suplantar inconvenientes políticos que de outra forma desaconselhariam a exportação;

$\mathrm{V}$. as vantagens comerciais de fornecimento determinado, em termos de rendimento econômico intrínseco ou multiplicador de vendas no mesmo ou outros mercados, podem, em perspectiva mais mediata, converter-se em vantagens também políticas (...);

VI. o comportamento dos demais supridores deve pesar na consideração das vantagens e desvantagens políticas de fornecimento determinado. O não fornecimento pelo Brasil pode evitar indesejável envolvimento político em atrito que Ihe traria desgaste, mas não impedirá, onde existirem fornecimentos alheios, presença maior de material bélico na área em conflito;

VII. poderá ocorrer situação em que seja aconselhável assegurar o próprio Brasil fornecimento em principio desvantajoso politicamente (e mesmo no plano comercial), mas necessário para evitar-se que terceiro fornecedor assuma condição de influir em conflito suscetível de afetar interesses políticos brasileiros;

VIII. também poderá ocorrer situação na qual se recomende fornecimento para evitar seja comprado, a terceiros, equipamento cujas características tornem sua presença no mercado importador inconveniente para os interesses políticos e de segurança do País e de suas relações com os países em atrito, atual ou potencial, com o da importação (...);

IX. para o exportador de armas, o melhor cliente é, por definição, o que se encontra em dificuldades. O principio mereceria numerosas qualificações, mas como regra o mercado para material de emprego militar cresce em razão direta da instabilidade interna ou nas relações externas do país comprador. Tráta-se de realidade penosa, mas inelutável e que não pode decerto ignorar ou desmerecer na execução de uma Política concebida para estimular as exportações nacionais de material de uso por Forças Armadas;

$X$. o princípio pode ser falacioso e já foi aplicado interessadamente em numerosas ocasiões. Pode no entanto surgir, como já surgiu, situação em que o fornecimento de material de emprego militar a países em conflito contribua para encaminhar negociações de outra forma inviáveis ou preservar um status-quo insatisfatório mais ainda assim de relativa tranquilidade. ${ }^{5}$

5 Antônio F. Azeredo da Silveira a Hugo de Andrade Abreu, Memorando secreto (DPG/DCS/DSI), Brasília, s.f. [circa maio de 1977], AHMRE: Pasta Especial PNEMEM-EI Salvador. 
O decálogo anterior é sumamente importante para os fins deste artigo, dado que atinge os aspectos fundamentais da política brasileira de exportação de armas vigente entre 1974 e $1991 .{ }^{6}$ Com base em tais antecedentes, cabe indagar-se: como se implementava o processo de tomada de decisões sobre a exportação de material de emprego militar e que atores participavam dele? Segundo a lógica burocrática própria da PNEMEM a exportação de material de emprego militar realizava-se mediante um sistema de licenças governamentais. ${ }^{7}$ Tal sistema de exportação de armas sob licença governamental era dirigido, conjuntamente, pelo Itamaraty e pela Secretaria Geral do Conselho de Segurança Nacional.

Todavia, o processo de transferência de material de emprego militar deveria recorrer por três fases burocráticas mais ou menos claras. Primeiro, os representantes comerciais das empresas brasileiras nos diferentes países realizavam uma agressiva promoção dos produtos susceptíveis de eventual exportação. Vale sublinhar a ênfase da estratégia comercial no lado da oferta. Os métodos de promoção comercial mais utilizados pelo governo e pelas empresas privadas brasileiras incluíam: demonstrações de produtos, a participação das empresas em feiras internacionais do setor da defesa, a confecção e atualização de catálogos com o equipamento militar disponível, a emissão de solicitações de apoio e pesquisa de mercado às embaixadas brasileiras, e o treinamento de oficiais estrangeiros em academias militares brasileiras - subentendendo-se que eventualmente ditos oficiais promoveriam a aquisição de produtos brasileiros para as suas respectivas forças armadas. ${ }^{8}$ Em consequência, nesta primeira fase os atores

6 Ponderações adicionais na política de transferência de armas incluíam: (i) a não-exportação de armas a zonas em tensão ou em guerra aberta; (ii) a análise de solicitações padronizadas caso a caso; (iii) a definição e classificação das armas de acordo com a natureza do produto e não da qualidade de quem a adquire ou vai utilizá-la; (iv) a não-exportação de armamento a governos com propósitos agressivos com respeito de terceiros países ou para implementar desaforada repressão interna; (v) a preocupação e auto-restrição à introdução de armamento tecnologicamente avançado em regiões com equilíbrios estratégicos mais ou menos satisfatórios; (vi) o evitar os juízos de valor sobre a natureza do governo e a política interna do país receptor; (vii) a venda de armas primordialmente a outros governos, exceto em casos especiais nos quais empresas privadas com aval governamental adquirem armamento ligeiro; e/ou, (viii) o desejo de evitar discriminações involuntárias ou reações adversas ao provedor entre os estados vizinhos do receptor. Parece oportuno acrescentar que normalmente os governos dos países fornecedores justificam a exportação de material de emprego militar também por razões: (i) econômicas, tais como a promoção de exportações com alto valor agregado, a recuperação de inversões em pesquisa e desenvolvimento, a redução dos custos unitários dos produtos de defesa adquiridos pelo próprio governo para abastecer as forças armadas locais, o estímulo ao crescimento econômico, o fato de garantir a continuidade do complexo militar-industrial; (ii) sociais, tais como a promoção do desenvolvimento regional, a redução do desemprego, o aprimoramento do capital humano; e (iii) estratégicas, isto é, o reforço e operacionalização das alianças e pactos militares.

7 O sistema de exportação de armas sob licença governamental foi introduzido, a nível mundial, na década de 1930.

8 Note-se, por exemplo, que em uma data tão precoce como outubro de 1970 o Encarregado de Negócios do Brasil em Tegucigalpa, Jayro Coelho, ao analisar as possíveis consequências do oferecimento de bolsas de estudo para militares hondurenhos em academias militares brasileiras, ponderou que "No que se refere às vantagens para o Brasil na concessão de tal tipo de bolsa, permito-me assinalar que, a longo prazo, podem os Oficiais formados no Brasil facilitar a introdução de armamentos brasileiros, especialmente armas portáteis para os corpos policiais, que aqui são parte integrante do Exército. Do mesmo modo, poder-se-á colocar, eventualmente, material de comunicações, equipamento de Engenharia e, no setor aeronáutico, Honduras pode vir a ser mercado para os aviões fabricados pela Embraer, mais especialmente, o 'Ipanema' e o 'Bandeirantes'." Jayro Coelho ao Ministério das Relações Exteriores, Ofício confidencial n. 131, Tegucigalpa, 8.10.1970, AHMRE: 622.7 (24c) (42). Em 1977, 
mais relevantes são (ou eram) os agentes das empresas brasileiras e os governos estrangeiros.

A segunda fase incluía a solicitação da licença preliminar das empresas exportadoras brasileiras junto às autoridades do Ministério das Relações Exteriores para aprofundar entendimentos com governos estrangeiros. Normalmente as autoridades do Itamaraty, em comum acordo com a Secretaria-Geral do Conselho de Segurança Nacional, que era a outra grande instância legalmente responsável pelo direcionamento da PNEMEM, outorgavam a licença preliminar, fundamentado na situação política, econômica e estratégica do país comprador e no possível impacto que a eventual transação poderia terminar gerando na imagem internacional e na política exterior global do Brasil.

Entretanto, algumas vezes, nesta segunda fase iniciava-se um processo mais ou menos complexo de negociação interburocrática. De um lado, se encontravam as autoridades ministeriais mais diretamente relacionadas com o complexo industrial-militar, com eventual apoio das autoridades de finanças e comércio exterior. Estes atores argumentavam que a exportação de armamento podia ser atrativa e inclusive vital para garantir a viabilidade e continuidade operacional da indústria de armamento. Em consequência, estes atores estavam mais interessados nos aspectos econômicos que nos aspectos políticos e internacionais das eventuais exportações. ${ }^{9}$ Por outro lado, estavam as autoridades diplomáticas, preocupadas com o impacto que a eventual exportação de armamento poderia vir provocar na política exterior global e na inserção internacional do país a médio e longo prazo. Nesta ordem de idéias, sob o ponto de vista político, tornava-se possível e provável que a exportação de material de emprego militar provocasse, em certos casos, conflitos de natureza interburocrática, em que as burocracias militar e diplomática terminavam encontrando-se em lados opostos, dentro do processo de tomada de decisões sobre o tema.

A terceira fase ocorre (ou ocorria) quando se aprovava a autorização definitiva para proceder à exportação do correspondente material de emprego militar. Nesta fase se subentendia que a transação era vantajosa sob os pontos de vista político, econômico e estratégico para as empresas, para o governo do país exportador e para o governo do país receptor. Note-se que a última palavra sobre exportação de armas brasileiras correspondia à pró-

o Embaixador brasileiro em Tegucigalpa, O. L. de Berenguer Cesar informou aos seus superiores no Itamaraty, que: "A iniciativa das Forças Armadas brasileiras de oferecerem a militares hondurenhos a oportunidade de se candidatarem a cursos especializados no Brasil constitui, a rigor, um investimento a longo prazo [...]". Entre outras razões, por seus possíveis desdobramentos no que diz respeito a eventuais vendas de material de emprego militar ao país centro-americano. O. L. de Berenguer César a MRE, Ofício confidencial (DCS), Tegucigalpa, 22.12.1977, AHMRE: Cx 132

9 No Brasil, como na França, as transferências de armas eram na realidade um meio, e não um fim, para garantir a viabilidade da indústria da defesa. Em ambos os casos a demanda interna de material de emprego militar era muito limitada para produzir as armas eficientemente. 
pria Presidência da República - sobretudo quando se tratava de armamento tecnologicamente avançado ou transações polêmicas e complexas.

Uma das melhores maneiras de verificar a lógica dos atores, particularmente dos funcionários do Itamaraty, no processo de tomada de decisões sobre a exportação de material de emprego militar é estudar casos específicos, como os das transferências de armamento para a América Central.

\section{A PNEMEM, a política externa brasileira e a América Central: análise de quatro experiências de tomada de decisões sobre even- tuais transferências de material de emprego militar de fabricação brasileira}

As solicitações dos governos da América Central para adquirir material de emprego militar no Brasil remontam, pelo menos, desde 1974. Naquela oportunidade o governo de El Salvador manifestou interesse por importar veículos blindados anfíbios de fabricação brasileira, com o propósito de empregá-los, segundo se informou desde São Salvador, na incipiente luta contra-insurgente. ${ }^{10}$ Posteriormente, à medida que os conflitos sociais e políticos do istmo se aprofundaram durante a segunda metade dos anos 1970, houve um persistente interesse dos autoritários governos da Guatemala, El Salvador, Honduras e Nicarágua em diversificar as suas fontes de abastecimento de armamento. Tais governos desejavam diversificar as suas fontes de abastecimento não só para satisfazer a crescente demanda interna, mas também para diminuir a forte pressão internacional - particularmente durante o governo do Presidente Jimmy Carter -, que culminou com embargos parciais de armas estadunidenses a três dos quatro países supracitados.

Do ponto de vista dos exportadores brasileiros o mercado de armamentos da América Central era atrativo. Apesar das reduzidas dimensões daquele mercado e da demanda de material pouco sofisticado tecnologicamente, existiam afinidades eletivas entre a demanda dos países centroamericanos e a oferta brasileira. Tratava-se basicamente de armamento de natureza contra-insurgente e de segurança pública (policial). Concretamente os centro-americanos demonstravam interesse por revólveres, espingardas, fuzis ligeiros, munição, vestuário, equipamento de comunicação e transporte e, excepcionalmente, armamento convencional avançado - sobretudo veículos blindados e aviões. Entre 1977 e 1989, dezessete empresas brasileiras vinculadas ao complexo industrial-militar expressaram ao Itamaraty o seu interesse em exportar material de emprego militar para o istmo e, para tan-

10 Hugo de Andrade Abreu a Antônio Francisco Azeredo da Silveira, Aviso n 326/74 (secreto), Brasília, 24.10.1974, AHMRE: Pasta Especial PNEMEM-El Salvador. 
to, submeteram-se ao sistema de licenças governamentais de exportação próprio da PNEMEM. ${ }^{11}$

Entretanto, o Departamento de Promoção Comercial, dirigido durante longo tempo pelo Ministro, e mais tarde Embaixador, Paulo Tarso Flecha de Lima, era o órgão específico no interior do Itamaraty onde se analisavam e resolviam grande parte das decisões sobre as condições e possibilidades de exportação de material de emprego militar - atendendo, vale insistir mais uma vez, aos objetivos, meios e riscos de natureza política, econômica e estratégica que cada solicitação supunha sob a perspectiva da política exterior global e da inserção internacional do país. Uma vez formada uma opinião institucional sobre a conveniência - ou não-conveniência - de exportar a certo país determinado material de emprego militar, esta era apresentada e sustentada diante dos outros atores institucionais responsáveis pela implementação da PNEMEM. Assim, a opinião institucional do Itamaraty era apresentada para consideração dos funcionários da Secretaria-Geral do Conselho de Segurança Nacional e, em alguns casos, em instâncias políticas ainda mais elevadas, inclusive na própria Presidência da República. ${ }^{12}$

Entre os aspectos mais surpreendentes e preocupantes para os funcionários do Itamaraty encarregados da análise do impacto político de eventuais exportações de material de emprego militar para os países da América Central - com a possível exceção da Costa Rica, que não tinha forças armadas - era que praticamente em todos os casos existia alguma restrição política relativamente importante. Tais restrições terminavam, na maioria dos casos, desaconselhando a autorização definitiva das transferências. Entre os casos selecionados mais expressivos do debate interno e formação de opinião institucional no Itamaraty sobre a conveniência - ou não-conveniência - de eventuais transferências de armas para os países da América Central durante os decênios de 1970 e 1980 vale destacar os seguintes:

Guatemala (1976). Em junho de 1976, funcionários do governo guatemalteco, então comandado pelo general Kjell Laugerud García (1974-1978), manifestaram aos agentes comerciais da empresa brasileira Engenheiros Especializados S. A. (ENGESA) o seu interesse pela aquisição de um conjunto de veículos blindados

11 As empresas brasileiras que expressaram ao Itamaraty interesse em exportar material de emprego militar para a América Central, entre 1977 e 1989, foram: Companhia de Explosivos Valparaíba, Explo-Indústrias Químicas de Explosivos, Empresa Brasileira de Aeronáutica S. A. (EMBRAER), Taurus S. A., Engenheiros Especializados S. A. (ENGESA), Bernardini S. A. Indústria e Comércio, Avibrás - Indústria Aeroespacial S. A., Companhia Brasileira de Cartuchos (CBC), PROTIN - Equipamentos Individuais de Proteção Ltda., HEDROAR S/A - Indústria Metalúrgica, Indústria de Material Bélico do Brasil (IMBEL), BRITANITE Indústrias Químicas Ltda., Helicópteros do Brasil S. A. (HELIBRÁS), DIANA Trading S. A., SPASA Trading S. A., Companhia de Comércio Exterior (CODECE), TUPAN - Comércio Internacional Ltda., Indústria e Comércio Beretta S. A., CORENA Metalurgia e Construções Navais S. A., Forjas Taurus, e, Indústria e Comércio de Máquinas e Peças Bilbao S. A.

12 Convém adiantar que este artigo se fundamenta basicamente na documentação resgatada no Arquivo Histórico do Ministério das Relações Exteriores. A documentação do Conselho de Segurança Nacional e da própria Presidência da República não foi consultada ainda. 
(E-9 Cascavel, E-11 Urutu e E-25 Caminhão Médio) produzidos por dita empresa, no valor total inicialmente estimado em US\$10 milhões - posteriormente elevado a US\$ 45 milhões. Seguindo os procedimentos normais da PNEMEM, a ENGESA solicitou a correspondente licença prévia para ampliar e aprofundar as negociações preliminares com o governo guatemalteco. Inicialmente os funcionários do Itamaraty comunicaram ao Conselho de Segurança Nacional e à empresa interessada que não existiam: "do ponto-de-vista do Ministério das Relações Exteriores, restrições de natureza política às transações pretendidas pela ENGESA. ${ }^{13}$

Contudo, a partir de outubro do mesmo ano, independentemente das negociações de natureza financeira, as considerações políticas da transação modificaram-se abruptamente, dado que o governo do Reino Unido comunicou à diplomacia brasileira sua preocupação pelo curso das negociações anglo-guatemaltecas em relação à independência de Belize e muito particularmente sobre a possível utilização das armas brasileiras porventura a ser transferidas em um ataque maciço do exército guatemalteco contra o território da colônia britânica. ${ }^{14}$ Configurou-se, assim, uma situação política delicada. A atrativa transferência de armamentos à Guatemala passaria a supor sérios riscos políticos para a política externa brasileira, particularmente no que se referia às relações com o Reino Unido, com alguns países do Caribe, com os Não-Alinhados e com alguns países ocidentais que respaldavam a irrestrita independência de Belize, no marco do processo de descolonização da região. ${ }^{15}$

A saída temporal que os funcionários do Itamaraty consideraram pertinente diante deste conflito de interesses foi a implementação de uma política de "compasso de espera". Assim, recomendou-se a ENGESA dilatar as negociações para ganhar tempo e observar cuidadosamente a tendência dos acontecimentos, sem que isso comprometesse negativamente a possibilidade de fazer efetiva a transferência do armamento à Guatemala - porém unicamente depois que a questão do direito de Belize à autodeterminação, à independência e à integridade territorial fosse completamente resolvida. ${ }^{16}$

13 Antônio F. Azeredo da Silveira a Hugo de Andrade Abreu, Minuta de Memorando secreto (DPG/DCS/67), Brasília, 9.7.1976, AHMRE: Pasta Especial PNEMEM-Guatemala.

14 MRE à DELBRASONU, Minuta de telegrama secreto (DPG), Brasília, 27.10.1976, AHMRE: Pasta Especial PNEMEM-Guatemala.

15 Vale agregar que até esse momento o governo brasileiro respaldava na ONU as reivindicações guatemaltecas - com votos favoráveis ou "abstenções amistosas". A partir de 1977, no entanto, o Brasil, como muitos outros países da América Latina e do Caribe, modificou sua postura e aceitou a tese da independência total de Belize, o que terminou ocorrendo em setembro de 1981. Everton Vieira Vargas ao Chefe, substituto, da DEA, Memorando confidencial (DEA/22), Brasília, 30.3.1979, AHMRE: Cx H-04 1979 (7).

16 Naturalmente, a política de dilatar as negociações não foi bem recebida pelos gerentes da ENGESA, devido ao temor de perder uma atrativa operação comercial. Tampouco pelo governo guatemalteco, interessado em ampliar e diversificar o seu inventario de armamento e fontes de abastecimento. Lembre-se que as forças armadas da Guatemala tinham preocupações com relação à questão de Belize e aos emergentes movimentos de libertação nacional - particularmente na região ocidental do país. Outrossim, a importação de material de emprego militar de fabricação brasileira poderia ser usado para demonstrar certa autonomia com relação à política externa do governo do Presidente Carter. Destarte, em 1977, a Guatemala importava armamento procedente de Taiwan, de Portugal, da Coréia do Sul, dos Estados Unidos, da Alemanha, da Índia e, especialmente, de Israel. 
Afinal, a transferência dos blindados brasileiros não se efetivou pela via direta, dado que a transação nunca foi autorizada oficialmente por funcionários do Itamaraty. No entanto, e inexplicavelmente, os Urutu e Cascavel da ENGESA terminaram sendo importados pela Guatemala. Os mesmos foram identificados naquele país, em 1982, no contexto do dramático conflito interno que azotava a nação centro-americana. ${ }^{17}$ Tal situação deixa entrever a possibilidade de triangulações comerciais, reexportações e/ou exportações ilegais de material de emprego militar de fabricação brasileira. O que naturalmente teria sido recebido com preocupação pela diplomacia brasileira devido ao negativo impacto político na imagem do país e, sobretudo, na sua capacidade de controle sobre as conhecidas tendências expansivas da indústria de defesa.

\section{El Salvador e Honduras (1977).}

No primeiro semestre de 1977 os funcionários do Itamaraty encarregados da PNEMEM se encontraram diante de uma interessante conjuntura colocada pelo simultâneo interesse dos governos de El Salvador e Honduras por produtos da indústria de armamentos brasileira. Parece oportuno acrescentar que, então, ambos os países conviviam numa tensa situação pós-bélica. ${ }^{18}$ Também, que o Brasil não tinha interesses econômicos, políticos ou estratégicos vitais na região. Ademais, o Brasil era um dos países membros da Reunião de Consulta Interamericana da OEA responsável por ajudar a encontrar uma solução para os problemas ainda existentes entre salvadorenhos e hondurenhos.

Em tais circunstâncias, a empresa Mercedes-Benz do Brasil consultou ao Itamaraty sobre a possibilidade de exportar para Honduras o caminhão LG-1213, versão de exército, com o qual o representante da firma em Tegucigalpa desejaria promover possíveis vendas de material brasileiro, a fim de aproveitar a oportunidade que se estaria apresentando no mercado daquele país, em função da renovação da frota de transporte das suas forças armadas. Paralelamente, as autoridades salvadorenhas manifestaram ao Embaixador brasileiro em São Salvador o interesse na compra de doze veículos blindados e alguns aviões EMB-326 GB Xavante e EMB-111 Bandeirante.

Dentre todos aqueles produtos somente o avião EMB-111 Bandeirante, na sua versão civil ou de passageiros, estaria fora do controle da PNEMEM e, portanto, liberado para ser exportado. Em contraste, os veículos blindados e

17 Guatemala usa Urutu e Cascavel para combate a guerrilha. Jornal do Brasil, 25.2.1982

18 Em julho de 1969, ambos os países enfrentaram-se militarmente na chamada Guerra das Cem Horas ou Guerra do Futebol. Até a assinatura do Tratado Geral de Paz (de 1980), São Salvador e Tegucigalpa conviveram em virtual guerra fria, apesar dos esforços da OEA para promover a restauração dos vínculos diplomáticos e consulares, e resolver a centenária disputa fronteiriça. 
o avião EMB-326 GB Xavante pretendidos pelo governo salvadorenho eram, sim, considerados como material de emprego militar e, em consequência, sujeitos às restrições da PNEMEM.

Entretanto, o caminhão LG-1213, pretendido pelo governo de Honduras, encontrava-se em uma situação ambígua. Em princípio tratava-se de um produto de natureza civil - porém, com eventual uso militar - e, portanto, sob um ponto de vista estritamente técnico estaria fora dos controles da PNEMEM. Ainda assim, sob um ponto de vista político a livre exportação desse caminhão civil - na sua versão militar - para abastecer o exército hondurenho poderia ser interpretado por terceiros (especialmente pelo governo salvadorenho) como equipamento efetivamente militar, o que poderia vir a dar lugar a uma aparente discriminação do governo brasileiro em favor das pretensões hondurenhas. Tal hipótese poderia terminar derivando em indesejáveis repercussões negativas nas relações políticas bilaterais brasileiro-salvadorenhas. E, por último, do ponto de vista da política exterior brasileira a transferência de ditos produtos poderia vir a provocar riscos políticos importantes, debilmente compensados pelas limitadas vantagens econômicas das transações.

Assim, a diplomacia brasileira, segundo consta em memorando interno do Itamaraty, ${ }^{19}$ terminou identificando quatro alternativas de ação diante das pretensões de hondurenhos e salvadorenhos: (i) interpretar o caminhão LG-1213 da Mercedes-Benz do Brasil pretendido pelo governo hondurenho como material de emprego militar e, portanto, sujeito à PNEMEM, (ii) autorizar à Mercedes-Benz do Brasil a exportação dos caminhões LG-1213 ao governo de Honduras, mas somente na sua versão civil, subentendo-se que a noção material de emprego militar define-se pela natureza efetivamente militar do produto e não por quem o adquire, (iii) autorizar à Mercedes-Benz do Brasil a venda dos caminhões LG-1213, na sua versão militar, "esperando-se" que dita transferência não fosse interpretada por terceiros (especialmente pelo governo salvadorenho) como exportação de equipamento militar e discriminatório em favor das pretensões hondurenhas, o que possivelmente implicaria reações negativas nas relações brasileirosalvadorenhas, e/ou (iv) implementar uma política de simetria positiva diante dos requerimentos de ambos os governos.

Lamentavelmente não se conseguiu verificar documentalmente no Arquivo Histórico do Ministério das Relações Exteriores (AHMRE) se todos ou parte daqueles produtos foram efetivamente transferidos aos respectivos países, nem tampouco se o critério de política de transferência foi algum

19 Antônio F. Azeredo da Silveira a Hugo de Andrade Abreu, Memorando secreto, Brasília, s.f. [circa 12.5.1977], AHMRE: Pasta Especial PNEMEM-EI Salvador. 
dos quatro anteriormente citados ou outro. ${ }^{20} \mathrm{Em}$ todo caso, o que interessa ressaltar aqui é que é justamente no processo de tomada de decisões sobre eventuais exportações de armamento onde pode constatar-se que cada transferência de armamento supõe uma atualização da política externa do país provedor com relação ao país receptor (e vice-versa). Portanto, vale confirmar o caráter essencialmente político, inclusive de política bilateral, inerente ao comércio internacional de armamento ou material de emprego militar de fabricação brasileira.

Nicarágua (1977-1979). A partir de 1977, o estado somozista iniciou sua etapa final de decomposição. O governo do país era acossado tanto no âmbito interno quanto externo. No plano doméstico pela oposição armada dirigida pelos sandinistas e pela oposição não-violenta de expressivos atores sociais e políticos. No âmbito externo o governo nicaraguense experimentava um persistente questionamento da sua legitimidade em diferentes foros internacionais, especialmente na OEA. Até o próprio governo dos Estados Unidos - na administração Carter (1977-1981) - retirou o seu tradicional apoio político, econômico e militar à dinastia da família Somoza na Nicarágua. ${ }^{21}$ Nesse contexto, o regime comandado pelo general Somoza encontrou-se diante da imperiosa necessidade de procurar fontes alternativas de abastecimento de armamento em estados ideologicamente afins e dispostos a vender-lhe as armas que tanto necessitava. Tal era o caso dos governos anticomunistas da Argentina, de Israel, de Portugal e, surpreendentemente, também do Brasil.

Os contatos iniciais entre o regime somozista e as empresas exportadoras brasileiras - a ENGESA e a EMBRAER - datam de 1976. Estes precoces contatos, que gozaram da aprovação do Itamaraty, intensificaram-se notoriamente em 1977, quando empresas brasileiras efetivamente exportaram armas para o país centro-americano. Tratou-se, na sua maior parte, de armas ligeiras (como revólveres, espingardas e carabinas), por um valor aproximado de US\$15 mil. Ao mesmo tempo, aprofundaram-se as negociações com a EMBRAER para a eventual exportação de aviões EMB-111 Bandeirante e EMB-326 GB Xavante, com a correspondente assistência técnica e facilidades de financiamento. ${ }^{22}$ Procedimentos semelhantes se realizaram entre

20 O mais provável é que as transferências não tenham sido efetuadas. Isto porque documentação posterior sugere que o Brasil começou a exportar ditos produtos depois da assinatura, em 1980, do Tratado Geral de Paz entre ambos os países.

21 Tenha-se presente que a política de proteção dos direitos humanos implementada durante o governo do Presidente Jimmy Carter supôs, entre outras coisas, a imposição de embargo de armas estadunidenses e/ou a denúncia de tratados de assistência militar entre os Estados Unidos e vários países da América Latina. Os países latinoamericanos que sofreram restrições à transferência de armamento de fabricação estadunidense por razões de abusiva repressão interna e insuficiente proteção aos direitos humanos foram: Argentina, Brasil, Chile, El Salvador, Guatemala, Nicarágua e Uruguai.

22 Em reconhecimento e agradecimento, o Ministro da Defesa do regime somozista declarou ao Embaixador brasileiro em Manágua que: "O governo da Nicarágua se defronta hoje com uma política de hostilidade de parte dos americanos". Acrescentando seguidamente que "[a] Nicarágua, como os demais países da área em idêntica situação contempla a postura do Brasil, diante do governo de Washington, como uma reafirmação de sua sólida 
o governo nicaraguense e a ENGESA, procurando a eventual transferência de veículos blindados para o país centro-americano.

A política de transferência de material de emprego militar de fabricação brasileira para a Nicarágua somozista experimentou uma importante modificação a partir de março de 1978. Na oportunidade, o governo da Nicarágua expressou ao governo do Brasil - isto é, durante a administração do general Ernesto Geisel - o seu interesse em intensificar dramaticamente suas importações de armas brasileiras. Para tanto, Manágua apresentou um listado de armas e munições que urgentemente necessitava. Em termos operativos tratava-se de um virtual pacote de assistência militar, que incluía a transferência de veículos blindados, armas ligeiras, munição, dentre outros. Seguindo os parâmetros da PNEMEM, a partir de abril iniciaram os debates no interior do Itamaraty sobre as vantagens e as desvantagens políticas, econômicas e estratégicas que o virtual pacote de ajuda militar brasileira ao cambaleante regime de Anastásio Somoza poderia vir a provocar na política exterior global do Brasil - considerando-se ademais que, até o momento, as empresas exportadoras brasileiras tinham tido orientações favoráveis à exportação de armas para a Nicarágua somozista.

Do debate correspondente participaram vários funcionários da Chancelaria brasileira, especialmente diplomatas pertencentes ao Departamento de Promoção Comercial (DPC) e à Divisão da América Central e Setentrional (DCS). Vale ressaltar que, como parte do debate, o secretário Sérgio Sanginito Novaes da Silva, pertencente à DCS, ponderou que: "O governo Somoza enfrenta forte contestação interna (...), [e] não apresenta boa imagem ao exterior. Não me parece oportuna qualquer aproximação política do Brasil com a Nicarágua, tendo em vista a situação interna e externa do seu governo." Em consequência, o secretário da Silva se opôs à eventual transferência de material de emprego militar para Manágua, argumentando - clara e categoricamente - que: "A venda de material de emprego militar representa, a meu ver, fato sobretudo político". ${ }^{23}$

Com efeito, a transferência de armas, sobretudo em momentos de tensão e conflitos internos ou internacionais, pode ser facilmente considerada como uma indevida intromissão nos assuntos internos de outros estados. Também pode ser interpretada como expressão de apoio, direto ou indireto, do governo do país exportador a uma das partes em conflito - neste caso ao regime de Somoza, o que possivelmente não era do interesse da política externa brasileira para a Nicarágua, em particular, e para a América Central, em geral. Adicionalmente, do ponto de vista econômico,

liderança, a qual está sendo particularmente apreciada entre as nações irmãs do continente". Deseta ao MRE, Telegrama confidencial (DCS), Manágua, 12.11.1977, AHMRE: Pasta Especial PNEMEM-Nicarágua.

23 Sérgio Sanginito Novaes da Silva ao Chefe da DCS, Despacho a Memorando Secreto (DPG/59/78), Brasília, 4.5.1978, AHMRE: Pasta Especial PNEMEM-Nicarágua. 
o montante da transação, ao que parece, não era suficientemente atrativo para compensar o severo desgaste político que a exportação do pacote de material de emprego militar poderia vir a provocar na política exterior global do Brasil. Em suma, os funcionários do Itamaraty chegaram ao consenso de que se tratava de uma transação com baixas vantagens econômicas e muito altas desvantagens políticas - isto é, espúria para os interesses do país.

Essa opinião institucional contrária à exportação de material de emprego militar para a Nicarágua somozista terminou sendo sustentada pelo próprio Chanceler Antônio F. Azeredo da Silveira quando informou, em julho de 1978, ao secretário-geral do Conselho de Segurança Nacional que, tendo em vista os consideráveis riscos políticos e baixos benefícios econômicos: "sou de opinião de que, no momento, não são aconselháveis gestões ou entendimentos com o governo da Nicarágua, com vistas a possíveis vendas de material de emprego militar brasileiro às Forças Armadas daquele país, no resguardo dos altos interesses nacionais de política externa." Ademais, o Chanceler colocou a urgente necessidade de evitar novas licenças favoráveis a exportadores brasileiros, bem como a necessidade de "alertar as firmas brasileiras já oficialmente autorizadas a realizar negociações preliminares com o governo da Nicarágua para que sustem, até nova orientação, os entendimentos porventura já em curso a esse respeito com autoridades daquele país". ${ }^{24}$

Naturalmente, e como no caso da venda de armas para a Guatemala, a política de ganhar tempo e protelar as negociações de eventuais transferências de material de emprego militar foi mal recebida por representantes do complexo industrial-militar brasileiro e pelo acossado governo somozista. Em relação aos primeiros, possivelmente o mais polêmico foi a (desaforada) declaração à imprensa de um general brasileiro, não identificado, quem chegou a expressar, entre outras ponderações, o seguinte:

Qual a diferença entre se vender Coca-Cola e se vender armas?'. A pergunta foi feita ontem, no Alto Comando do Exército, por um oficial-general, segundo a Agência Estado. O repórter havia perguntado o que ele achava sobre a venda de armas ao governo da Nicarágua. 'Não podemos agir com romantismo, tentado argumentar com os governos sobre a sua necessidade de compra ou não de armamentos. Pois bem, se o governo de Somoza nos bate a porta à procura de armas e nós, por razões políticas quaisquer, nos negamos a fornecer, o que vai acontecer? Ele procura outro [fornecedor]. Da mesma forma que não podemos admitir a interferência na nossa soberania, é um problema dele o que eles compram ou não'.

O general comentou os eventuais riscos políticos de vender armas a Anastásio

24 Antônio F. Azeredo da Silveira a Gustavo Moraes Rego Reis, Memorando secreto (DPG/DCS/DSI/84), Brasília, 25.7.1978, AHMRE: Pasta Especial PNEMEM-Nicarágua. 
Somoza ou Augusto Pinochet. 'Quem faz a guerra são eles [os nicaraguenses] e não nós. Mesmo que nós não vendêssemos armamentos eles os conseguiriam de outra forma'. ${ }^{25}$

Essas declarações foram posteriormente desmentidas pelo Palácio do Planalto, pelo Itamaraty e inclusive pelo Quartel Geral do Exército. ${ }^{26}$ Mesmo assim, durante a segunda metade de 1978 e o primeiro semestre de 1979 rumores e relatórios jornalísticos - mais ou menos confiáveis - continuaram publicando manchetes sobre possíveis, sigilosas e ilegais transferências de armas de fabricação brasileira destinadas a sustentar o esforço bélico do regime somozista. Ditas transferências se realizariam através de diferentes mecanismos pouco transparentes, incluindo-se as triangulações comerciais. ${ }^{27}$

Note-se que os próprios dirigentes da Frente Sandinista de Libertação Nacional, no contexto da insurreição final, denunciaram energicamente as possíveis transferências de material de emprego militar de fabricação brasileira e acusaram o governo do Presidente Figueiredo de continuar respaldando o agonizante regime do general Anastásio Somoza. Concretamente a elite revolucionária sandinista ter-se-ia manifestado nos seguintes termos: "Acusamos os governos de Israel, Brasil, Argentina, Guatemala e El Salvador de estarem ajudando à ditadura [somozista] e os advertimos de que em seu devido momento nosso povo fará valer a justiça popular". ${ }^{28}$

Tem pouca informação disponível no momento sobre a reação do agonizante regime somozista diante do virtual embargo de armas brasileiras. Entretanto, sabe-se que alguns meses antes do triunfo da revolução popular sandinista o próprio general Somoza se reuniu com funcionários da Embaixada brasileira em Manágua para tratar de agilizar a importação do armamento previamente negociado com a ENGESA e a abertura de novas linhas de crédito para financiar compras de armas no Brasil. Agora se sabe que o ditador nicaraguense não logrou adquirir armas brasileiras devido a uma política explicitamente formulada para negar-lhe o aceso às mesmas. Em consequência, diante das reiteradas petições do governo nicaraguense à Embaixada brasileira em Manágua, o Embaixador foi autorizado pelas autoridades do Itamaraty a expressar-lhe verbalmente ao Presidente Somoza que

25 General brasileiro quer vender armas a Somoza. Jornal de Brasília, p.3, 8.6.1979.

26 Brasil não vende armas. Jornal de Brasília, p.5, 9.6.1979. Também: Itamaraty desmente pedido de ajuda. O Estado de São Paulo, p.4, 27/06/1979.

27 Macesoares ao MRE, Telegrama confidencial (DCS/DPG/AIG), Cidade do Panamá, 16.1.1979, AHMRE: Pasta Especial PNEMEM-Nicarágua.

28 Cit. LUCA, Walmor de. Discurso na Câmara dos Deputados. Diário do Congresso Nacional, 23.6.1979, p.6444. O Deputado Federal Walmor de Luca (MDB-SC) era um dos líderes políticos que pressionavam o governo do Presidente Figueiredo para uma ruptura das relações diplomáticas com o regime comandado pelo general Somoza. 
tendo em vista que já se iniciaram, no foro competente, os entendimentos visando à conciliação entre a Nicarágua e demais países centro-americanos, o governo brasileiro não julga construtivo tomar medidas que possam caracterizar um favorecimento a qualquer uma das partes envolvidas nesse processo. Vossa Excelência deverá assinalar, a propósito, que a resolução da OEA sobre o assunto contou não apenas com a concordância do governo desse país como também com o apoio do Brasil, que, portanto, se vê impossibilitado de considerar, nas atuais circunstâncias, a venda de equipamento militar para a Nicarágua. ${ }^{29}$

\section{Contra-revolucionários nicaraguenses}

Três das consequências mais dramáticas da decisiva derrota militar argentina na Guerra das Malvinas foram: o acelerado retorno do país à ordem constitucional, a firme vontade do novo governo argentino de modificar substancialmente a política externa global e a política de transferência de armas, ${ }^{30}$ e sobretudo a supressão do infame pacto anticomunista argentino-estadunidense-hondurenho na América Central, cujo foco centrava-se na agressão ao regime sandinista através dos tristemente célebres grupos rebeldes anti-sandinistas ou "contras", originalmente criados, treinados e abastecidos de armas pelos assessores militares argentinos em Honduras.

A retirada dos assessores militares argentinos de Honduras, de El Salvador e da Guatemala supôs um duro golpe na cruzada anticomunista da administração Reagan na América Central. A partir de 1983, tornou-se necessário para a comunidade de inteligência estadunidense e de seus aliados buscar novas fontes de abastecimento relativamente sigilosas, para garantir a continuidade da estratégia de conflito de baixa intensidade ou guerra de desgaste implementada contra o regime sandinista - sem que isso implicasse um envolvimento direto do governo dos Estados Unidos, devido às restrições impostas pelo Congresso daquele país à administração Reagan.

Entretanto, no Brasil, a política de transferência de armamento experimentou, em 1980, uma significativa mudança, autorizando-se a venda de armas tanto para governos quanto para empresas privadas que contassem com o aval do governo de seu país de origem. Dita modificação, ao que tudo indica, foi realizada para intensificar as exportações de material de emprego militar, no contexto geral de um mercado internacional altamente competitivo. Contudo, tal modificação na PNEMEM deu lugar a uma pouco conhecida, surpreendente e perturbadora transferência de armamento brasileiro para os "contras" nicaraguenses, através de empresas privadas

29 MRE à Embaixada em Manágua, Minuta de telegrama secreto-urgentísimo, Brasília, 16.10.1978, AHMRE: Pasta Especial PNEMEM-Nicarágua.

30 DIEHL, Jackson. Argentina Sends More Weapons to Central América. The Washington Post, p.8, 10/06/1984. 
estadunidenses vinculadas à comunidade de inteligência e a grupos empresariais conservadores daquele país.

Não está claro quando iniciaram os embarques de material de emprego militar destinado aos "contras" nicaraguenses, aparentemente sem conhecimento das autoridades brasileiras. As primeiras notícias disponíveis sobre o tema são de julho de 1984, quando se denunciou desde Porto Rico que um certo navio Freedom, de bandeira panamenha e possivelmente fretado pela CIA, transportava dinamite e outros explosivos fabricados no Brasil, que seriam desembarcados no porto costarriquenho de Limón, e cujo destino final seriam as forças "contras" que operavam na Costa Rica. Vale sublinhar, que tais informações terminaram sendo, sigilosamente, confirmadas às autoridades do Itamaraty por funcionários da Embaixada brasileira em Manágua. ${ }^{31}$ Ainda não se sabe qual foi a reação das autoridades sandinistas ou o impacto que este caso pode ter provocado nas relações políticas bilaterais brasileiro-nicaraguenses.

O maior escândalo até agora conhecido e provocado pela política de transferência de armas brasileiras para empresas privadas estadunidenses e, posteriormente, destinadas aos "contras" teve lugar em outubro de 1986. $\mathrm{Na}$ oportunidade, os jornalistas Jack Anderson e Dale van Atta informaram que fuzis e outros tipos de armas de fabricação brasileira, com valor aproximado de US\$2,8 milhões, importados pela empresa estadunidense Sherwood International Export Corporation, entre 1982 e 1983, puderam ter sido transferidos para os "contras" e outros grupos rebeldes anticomunistas que lutavam em Angola e no Afeganistão - isto é, os freedom fighters como preferia chamar-Ihes o Presidente Reagan -, apoiados pela CIA. ${ }^{32}$

Essa manchete provocou importantes repercussões no Brasil do Presidente Sarney e em outros países, sobretudo na Nicarágua e em Angola. De acordo com as autoridades brasileiras uma vez que as exportações de armas eram autorizadas a responsabilidade política emanada das mesmas passava a ser do governo ou da empresa privada com o aval governamental que as adquiria, já que o governo brasileiro careceria de mecanismos de controle sobre o uso ou destino final do armamento exportado. Neste caso tratar-se-ia, segundo informações da imprensa, de "40 mil rifles de

31 Luiz Fernando Nazareth ao MRE, Telegrama ostensivo (DCS/DPG), Manágua, 9.7.1984, AHMRE: Pasta Especial PNEMEM-Nicarágua.

32 ATTA, Jack Anderson e Dale van. "CIA Shipped Arms From Brazil, India", The Washington Post, p.10, 17.10.1986 A veracidade desta manchete foi, sigilosamente, confirmada às autoridades do Itamaraty por funcionários da Embaixada brasileira em Washington. Constatou-se que efetivamente a empresa Sherwood International Export Corporation tinha adquirido material de emprego militar brasileiro fabricado por Indústria de Material Bélico do Brasil (IMBEL). Ademais, a Embaixada brasileira em Washington informou que tais aquisições foram realizadas em 1982, 1983, 1984 e inclusive no próprio 1986. Os diplomatas brasileiros manifestaram que as transferências se realizaram através das respectivas licenças de importação concedidas pelo Bureau of Alcohol, Tobacco and Firearms (ATF) do Departamento do Tesouro do governo dos Estados Unidos. Serjocosta ao MRE, Telegrama confidencial-urgentíssimo (DIPROC/DCS/SEI/DAF-II/DAOC-I), Washington, 18.10.1986, AHMRE: Pasta Especial PNEMEM-Nicarágua II. 
fabricação brasileira em poder dos contra-revolucionários da Nicarágua". ${ }^{3}$ Lamentavelmente, ainda não se conhecem as reações do governo sandinista da época diante do tema, nem o impacto que ditas transferências de armas seguramente provocaram nas relações políticas bilaterais.

Igualmente, em dezembro de 1986 a revista brasileira Veja informou que várias caixas de granadas de mão fabricadas pela Companhia de Explosivos Valparaíba tinham sido fotografadas em um campo de treinamento dos "contras" em Honduras. Segundo investigações realizadas pelos repórteres daquela revista, a Companhia de Explosivos Valparaíba teria exportado, em 1984, devidamente autorizada pela PNEMEM, granadas de mão unicamente ao Sri Lanka e ao Uruguai, e que não tinham antecedentes de outras exportações dessa empresa. Tais incongruências, de acordo com a mesma fonte, poderiam erigir-se em "provas de que o governo brasileiro também está metido em negócios clandestinos que envolvem operações de vendas falsas, triangulações e desrespeito às diretrizes da política externa". "Por linhas tortas, armas brasileiras [dotadas de 'responsabilidade política irrecusável do governo do país exportador'] estão sendo usadas para matar pessoas num país com o qual o Brasil mantém relações diplomáticas" comentou a notícia. Em consequência, como sugeria a mesma fonte: "o governo da Nicarágua ganha[va] um excelente argumento para cobrar satisfações do Itamaraty". ${ }^{34}$

Durante o segundo semestre de 1987, houve duas novas referências com relação às armas de fabricação brasileira em poder ou destinadas aos "contras" nicaraguenses. Na primeira, publicada na revista Veja, o general da reserva Richard Secord, comprovadamente vinculado aos "contras", queixou-se da má qualidade das granadas de mão produzidas pela empresa Companhia de Explosivos Valparaíba. De acordo com a manchete, o ex-militar e mercenário estadunidense lamentou que: "as granadas de mão fabricadas no Brasil, que os contra-revolucionários nicaraguenses usam para combater o governo sandinista, explodem literalmente nas mãos dos guerrilheiros. 'É um problema de controle de qualidade bastante conhecido', diz o general". ${ }^{35}$

A última referência às armas de fabricação brasileira em poder ou destinadas aos "contras" de que se tem notícia no momento ocorreu no final de setembro de 1987, quando o diplomata Sérgio Duarte, funcionário da Embaixada brasileira em Manágua, informou a seu superior no Itamaraty que: "Em conferência de imprensa convocada pelo Ministério da Defesa da Nicarágua, foram exibidos diversos tipos de material bélico capturados pelo Exército Sandinista e que se destinava a abastecer os guerrilheiros contra-revolucionários. (...) Entre as armas exibidas contavam-se cerca de

33 ClA desvia armas brasileiras para os anti-sandinistas e Brasil não controla comprador. Jornal do Brasil, $1^{\circ}$ caderno, p.14, 18.10.1984.

34 A conexão brasileira. Veja, n 953, p.62-63, 10.12.1986. Ao que tudo indica, a transição democrática brasileira não implicou mudanças significativas no que diz respeito à política de comércio internacional de armas.

35 As apressadas. Veja, n 993, p.38, 16.9.1987. 
meia dúzia de fuzis 'Fal', de fabricação brasileira." Diante o negativo impacto que a possessão e utilização de armas de fabricação brasileira em poder dos "contras" poderia vir a provocar nas relações políticas bilaterais, Duarte solicitou ao seu superior em Brasília: "os subsídios que Vossa Excelência julgar pertinentes a respeito da política brasileira de exportação de armamento". ${ }^{36} \mathrm{Na}$ correspondente resposta, informou-se a Duarte que:
A 'Indústria de Material Bélico do Brasil - IMBEL' efetivamente vem exportando fuzis 'Fal', particularmente para importadores privados dos EUA, que constituem o principal mercado da empresa. Tráta-se de operações comerciais realizadas conforme as diretrizes da chamada 'Política Nacional de Exportação de Material de Emprego Militar' (PNEMEM). De acordo com a PNEMEM só são autorizadas vendas para Forças Armadas ou para empresas devidamente autorizadas a importar armamentos por seus governos.
Apesar do rigoroso controle em relação aos países destinatários - são proibi- das as exportações para o ISTMO Centro Americano, com exceção de armas de utilização por as forças policiais para a Costa Rica e o Panamá - o governo brasileiro não exige certificado de uso final dos compradores. Assim sendo, não se pode descartar a hipótese de que material legalmente vendido venha ser re- exportado pelo importador. É óbvio que as autoridades brasileiras não poderão ser responsabilizadas por reexportações. ${ }^{37}$

O texto anterior é bastante categórico, auto-explicativo e perturbador. Contudo, parece importante insistir em que a política brasileira de transferência de armamento tornou cada vez mais evidente o paradoxo que encerrava a política exterior do país. Por um lado, existia um virtual embargo de armas brasileiras para o istmo. Ademais, formalmente o governo brasileiro apoiava os esforços de pacificação na América Central promovidos pelo Grupo de Contadora. Porém, ao mesmo tempo, armas de fabricação brasileira, dotadas de "responsabilidade política irrecusável do governo do país exportador", continuavam sendo utilizadas no conflito armado interno da Nicarágua - que por sua vez fazia parte do conflito regional na América Central. ${ }^{38}$

\section{Conclusão}

Os quatro casos examinados neste artigo confirmam a existência de elos entre a PNEMEM e a política externa global, hemisférica e especificamente centro-americana do Brasil no período entre 1974 e 1991. O reconhecimento

36 Sérgio Duarte a MRE, Telegrama confidencial-urgentíssimo (DCS/DIC), Manágua, 30.9.1987, AHMRE: Pasta Especial PNEMEM-Nicarágua II.

37 MRE à Embaixada brasileira em Manágua, Minuta de telegrama confidencial-urgentíssimo (DPG/DCS), Brasília, 1.10.1987, AHMRE: Pasta Especial PNEMEM-Nicarágua II.

38 Dadas as limitações de espaço não é possível abordar neste artigo outros casos de exportação de armas de fabricação brasileira para os países da América Central, inclusive os aviões EMB-312 Tucano para Honduras e os relatos do uso de fuzis brasileiros pelos combatentes da Frente Farabundo Marti para a Libertação Nacional de El Salvador. 
da "responsabilidade política irrecusável do governo do país exportador" mencionada pelo então Chanceler Azeredo da Silveira é particularmente relevante e significativo. De fato, a colocação do ministro pode terminar sendo de interesse de muitos outros pesquisadores especializados na temática. A documentação primaria resgatada no Arquivo Histórico do Ministério das Relações Exteriores do Brasil também permite identificar outras diretrizes gerais sobre uma temática pouco estudada no país.

Igualmente, a documentação consultada permite constatar o persistente e continuado interesse dos - autoritários - governos centro-americanos pelas armas de fabricação brasileira, em função da favorável relação preçoqualidade, da lógica contra-insurgente com a que tinha sido fabricado, do prévio conhecimento destas pelos oficiais militares, e das considerações de natureza política e estratégica. Em termos abrangentes o artigo ilustra uma dimensão especifica das relações brasileiro-centro-americanas em um período complexo tanto no Brasil (abertura política) quanto nos países do istmo (conflito regional e processo de Contadora).

Outras contribuições do artigo permitem constatar que o comércio internacional de armas - ou material de emprego militar - é uma dimensão especial da política exterior dos países provedores e de seus clientes. Constatou-se, também, que durante o decênio de 1970, o incipiente complexo industrial-militar e as transferências de material de emprego militar de fabricação brasileira se expandiram de forma muito expressiva. Assim, em poucos anos o Brasil se transformou em um dos mais importantes exportadores de armas do mundo.

Essa dramática expansão das transferências de armamento supôs, entre outros aspectos, a necessidade de introduzir certas alterações nas diretrizes da política exterior brasileira. Daí a origem de um conjunto mais o menos articulado de critérios políticos, econômicos, ideológicos e estratégicos que culminaram, em 1974, com a formulação da chamada Política Nacional de Exportação de Material de Emprego Militar (PNEMEM).

Foi possível verificar documentalmente que algumas transferências provocaram interessantíssimas disputas interburocráticas que colocaram em lados opostos às autoridades diplomáticas e às autoridades relacionadas diretamente com o complexo industrial-militar (altos mandos militares, empresários). Os primeiros, preocupados com o possível impacto de determinada transferência na política externa global do país. Enquanto os segundos interessados em garantir a sobrevivência e expansão do setor.

Finalmente se constatou que a diplomacia brasileira vetou quase todos os contratos preliminares de eventuais exportações de material de emprego militar para a região centro-americana. Este virtual embargo de armas de fabricação brasileira foi reiterado pelo Chanceler Saraiva Guerreiro em 1983, como uma medida destinada a fortalecer politicamente o processo negociador de Contadora. 